\title{
RESENHA: ROCHA, INÊS DE ALMEIDA; IGAYARA-SOUZA, SUSANA CECÍlIA; MONTI, EDNARDO MONTEIRO GONZAGA DO (ORG.). SONS DE OUTRORA EM REFLEXÕES ATUAIS: HISTÓRIA DA EDUCAÇÃO E MÚSICA. CURITIBA: CRV, 2020. 272 P.
}

Book review: ROCHA, Inês de Almeida; IGAYARA-SOUZA, Susana Cecília; MONTI, Ednardo Monteiro Gonzaga do (org.). Sons de outrora em reflexões atuais: história da educação e música. Curitiba: CRV, 2020. $272 p$.
Reseña: ROCHA, Inês de Almeida; IGAYARASOUZA, Susana Cecília; MONTI, Ednardo Monteiro Gonzaga do (org.). Sons de outrora em reflexões atuais: história da educação e música. Curitiba: CRV, 2020. 272 p.

Camila Betina RöPKe

Universidade Federal do Piauí camilaropke@ufpi.edu.br

Este é um livro que tem como foco a história da educação musical e reúne pesquisas desenvolvidas no Brasil, Portugal e Espanha. Possui dois prefácios, um escrito por Libânia Xavier e outro, por Joaquim Pintassilgo. Foi organizado por Inês de Almeida Rocha, Susana Cecília Igayara-Souza e Ednardo Monteiro Gonzaga do Monti, professores líderes de grupos de pesquisa e que vêm desenvolvendo trabalhos sobre música, história e educação. É composto por 11 capítulos, envolvendo estudos de doutorado concluídos.

Todos os artigos trabalham com análise de fontes documentais. Entre as fontes utilizadas encontramos legislação, relatórios, cartas e fotos. Os autores, além de relatarem os tratamentos empregados na análise dos dados, descrevem detalhadamente os procedimentos adotados na localização e seleção das fontes. Os textos são também bem escritos, bem estruturados e possuem excelentes notas de rodapé, que auxiliam o leitor na compreensão de alguns elementos presentes nos artigos. Dessa forma, o livro é muito didático e pode auxiliar tanto os pesquisadores experientes como aqueles que estão iniciando na vida acadêmica. 
Podemos identificar esse detalhamento da metodologia e o zelo pela boa estrutura do texto logo no primeiro capitulo, escrito por Ana Luísa Paz. Nele a autora buscou compreender como a sociedade portuguesa identificava e definia um "gênio" da música entre os anos de 1868 e 1930. Paz relata quais as razões a levaram a selecionar determinado documento, quais suas expectativas quanto às informações contidas neles e quais de fato encontrou. Também é descrito detalhadamente todo o processo de categorização e análise dos materiais.

Para Cohen, Manion e Morrison (2007), a análise de documentos como cartas e diários possibilita contato com questões de foro íntimo. Essa abordagem fica evidente quando lemos o capitulo escrito por Inês de Almeida Rocha. Por meio da análise das cartas escritas por Liddy Chiaffarelli Mignone para Mário de Andrade é possivel perceber a amizade entre os dois e elementos da atuação de Liddy como artista e educadora.

Por meio da análise de cartas e demais documentos, Jane Borges busca descrever o repertório, a função da música e as práticas musicais das escolas americanas de confissão protestante de São Paulo, entre o final do século XIX e início do século XX. Borges aponta que havia uma forte valorização dos hinos religiosos e as práticas vocais eram as atividades mais difundidas dentro dessa comunidade.

Ednardo Monti, que entre outras fontes também analisa cartas, busca debater as relações politicas e pedagógicas entre Villa-Lobos e três signatários do Manifesto da Educação Nova: Anísio Teixeira, Afrânio Peixoto e Fernando Azevedo. Ele aponta que após a análise das fontes levantadas, é possivel observar uma clara relação entre as concepções educacionais desses intelectuais e o movimento orfeônico.

Assim como Monti, outros três textos voltam-se para o orfeonismo. Igayara-Souza investigou os objetivos artísticos da prática musical escolar. Sua análise aponta que as questões cívicas e morais eram privilegiadas nos documentos, contudo, os aspectos artísticos eram aqueles com maior grau de regulação. Valorizava-se a formação do professor, a execução musical, a afinação, a rítmica e a escolha do repertório.

Wilson Lemos Junior buscou investigar a formação de professores de música no Conservatório de Canto Orfeônico do Paraná entre os anos de 1956 e 1971. Aponta que o conservatório paranaense possuía uma estrutura curricular similar ao conservatório nacional. Os objetivos dessas instituições também eram semelhantes, utilizavam-se das atividades artísticas como ferramenta para a formação do cidadão.

O foco da pesquisa de Vanessa Weber de Castro é investigar o ensino de música nas escolas públicas do estado da Guanabara, entre 1960 e 1975. Após a análise de documentos e de entrevistas com educadores musicais da época, Castro aponta que mesmo com a mudança da legislação, muitas práticas orfeônicas continuaram acontecendo no Rio de Janeiro. Nesse contexto a Superintendência de Educação Musical e Artística (Sema) foi um importante agente em prol da educação musical.

O Rio de Janeiro também é o recorte espacial da pesquisa desenvolvida por Gilberto Vieira Garcia. Em seu capítulo, o autor discorre sobre os mestres 
de música que atuaram no Imperial Colégio de Pedro II entre 1838 e 1899. Diversos mestres/professores são abordados. Garcia aponta que, ao longo desse recorte temporal, a docência em música foi ganhando valorização e os professores passaram a se dedicar mais ao ensino do que às práticas musicais fora do colégio. Os sujeitos investigados eram homens, elemento natural à época tendo em vista que o colégio era masculino.

A educação musical de mulheres é o objeto de estudo de Ademir Adeodato. Nesse texto o autor busca compreender as trajetórias de quatro professoras que lecionaram música no final do século XIX no Colégio Nossa Senhora da Penha, primeira instituição destinada à educação feminina no estado do Espírito Santo. O autor aponta que as primeiras professoras, além da docência, eram também as diretoras da escola e trabalharam pela melhoria tanto dos aspectos curriculares como da sua estrutura física.

A educação musical feminina no século XIX é o foco da investigação de Nieves Hernández-Romero. Contudo, esse capítulo não mais se volta para a realidade brasileira, e sim para a espanhola. A autora aponta que a formação recebida pelas mulheres era frequentemente inferior àquela dada aos homens. A música era vista como "adorno" na busca de bons casamentos.

María del Rosario Castañón Rodriguez também investiga a educação musical na Espanha, contudo durante o regime franquista. Assim como Hernández-Romero, Castañón busca compreender a educação feminina, porém comparando-a com a recebida pelos meninos. A autora aponta que a educação era diferenciada por gênero e as atividades musicais tinham um forte caráter ideológico. Nas escolas masculinas, valorizavam-se as canções de exaltação à pátria e os hinos militares. Para as meninas, buscava-se a formação da mulher, dona de casa e mãe formadora de novos cidadãos. O repertório para elas incluía canções folclóricas e tradicionais espanholas, infantis, religiosas e hinos patrióticos.

Segundo Nóvoa (2011, p. 11), a história nos ajuda a compreender "quem fomos" e "como somos". Assim, o estudo da história da educação musical nos ajuda a conhecer as trajetórias e nossas atuais práticas pedagógicas. O livro Sons de outrora em reflexões atuais: história de educação e música contribui para juntarmos as peças deste grande quebra-cabeça que é a história da pedagogia musical. Certamente, muitas peças ainda precisam ser encontradas e encaixadas, contudo esse é um processo que deve ser feito amparado pelo trabalho já desenvolvido. Dessa forma, acredito que esse livro dá suporte para a compreensão de elementos da educação musical, bem como auxilia na busca da localização de novas informações.

\section{REFERENCIAS}

COHEN, Louis; MANION, Lawrence; MORRISON, Keith. Research methods in education. New York: Routledge, 2007.

NÓVOA, António. Por que história da educação?. In: STEPHANOU, Maria; BASTOS, Maria Helena Camara. Histórias e memórias da educação no Brasil: vol. I: séculos XVI-XVIII. Petrópolis: Vozes, 2011. p. 9-13. 
Camila Betina Röpke é natural de São Bento do Sul (SC), cidade na qual iniciou seus estudos musicais aos 8 anos de idade. Graduou-se em Licenciatura em Música pela Escola de Música e Belas Artes do Paraná (EMBAP), onde concluiu também uma especialização em Educação Musical. É mestre em educação musical pela Universidade Federal do Rio Grande do Sul (UFRGS) e doutoranda em Educação na Universidade Federal do Piauí (UFPI). Possui experiência com ensino de instrumento musical (flauta transversal, flauta doce e piano), teoria musical, musicalização infantil e musicalização de bebês. Atuou também como professora de música em escolas de educação básica. Atualmente é professora na UFPI. https://orcid.org/0000-0003-0221-9455 